\title{
AN EXPLANATORY MODEL OF THE ECOTOURISTS BEHAVIOUR: MANAGEMENT STRATEGIES FOR TOURISM SECTOR
}

\section{Carlota Lorenzo-Romero', María-del-Carmen Alarcón-del-Amo², José Alberto Crespo-Jareño ${ }^{3}$}

\footnotetext{
1 University of Castilla-La Mancha, Business Administration Department, Spain, ORCID: 0000-0002-0759-031X, carlota.lorenzo@uclm.es;

2 University of Murcia, Marketing Department, Spain, ORCID: 0000-0002-5195-3923, mcarmenalarcon@um.es;

3 University of Castilla-La Mancha, Business Administration Department, Spain, ORCID: 0000-0003-2237-4049, josealberto.crespo@uclm.es.
}

\begin{abstract}
Concern for the environment, which is of interest to academia, the business world and society in general, has meant the development of green marketing in the last half century. Environment can influence consumer behaviour and specifically the way tourists consume. The promotion of ecotourism, through information and communication, must be based on the identification of the different behaviour models to which marketing strategies are directed, according to needs, motivations, interests, expectations, behaviours and attitudes. The main research goal of this study is to determine the internal and external factors that influence the consumer behaviours identified as ecotourists, as well as the factors that shape their purchasing intentions. The theory of planned behaviour has shown its usefulness because its object (i.e., intention to perform a behaviour, taking into account that in the intentions are the factors that motivate the behaviour), through attitudes and beliefs, is the prediction and understanding of the way individuals behave. A model that facilitates the understanding of the ecological behaviour of ecotourists has been developed, starting from the value-belief-norm model towards the environment, to which a construct related to the theory of planned behaviour has been incorporated, in order to better understand the behaviour of ecotourists. The method used to analyse the causal model has been the structural equation modelling, and the sample used amounts to 403 ecotourists within a country characterized by the importance of tourism sector in its economic growing: Spain. The main result obtained indicates that the proposed model is useful to know the ecological behaviour of ecotourists. Specifically, it has been facilitated the knowledge of the factors that affect the intention to do ecotourism and to pay more to consume this type of activities. It could be useful for professionals of tourism sector to analyse and improve their ecological marketing strategies.
\end{abstract}

Keywords: Ecotourism, ecological behaviour, value-belief-norm model, structural equation modelling, social implications, Spain.

JEL Classification: J39, D02, L83, Z33.

APA Style Citation: Lorenzo-Romero, C., Alarcón-del-Amo, M.d.C., \& Crespo-Jareño, J. A. (2021). An Explanatory Model of the Ecotourists Behaviour: Management Strategies for Tourism Sector. E\&M Economics and Management, 24(3), 224-238. https://doi.org/10.15240/ tul/001/2021-3-013

\section{Introduction}

The academia finds it necessary to know which factors, whether internal or external to consumer behaviour, influence their purchasing behaviour of ecological or natural products or services, which in the field of tourism take the form of a new form of alternative tourism, either through nature tourism or ecotourism (Hultman et al., 2015). 
Within the research on consumer behaviour, studies have been carried out to understand the attitude of so-called ecotourists (Han, 2015; Kiatkawsin \& Han, 2017), but their ecological behaviour as consumers continues to be a field of research that offers diverse spaces for study, since the research is still scarce, especially in terms of knowledge of the importance of psychographic, personality, cultural, economic and demographic factors (Hultman et al., 2015; Kiatkawsin \& Han, 2017). Furthermore, the literature review emphasizes the need to deepen the understanding of environmentally responsible behaviour by incorporating the external, contextual, or group variables that influence such behaviour (López Miguens et al., 2015).

For all these reasons, we carried out a study related to the ecological behaviour factors of ecotourists in Spain. Specifically, the main aim of this study is to determine the internal and external factors that influence the consumer behaviours identified as ecotourists, as well as the factors that shape their purchasing intentions, to enabling a better understanding of the characteristics of ecotourists on which the thriving ecotourism market depends. The choice for our study is due to the current importance of ecotourism in this country. The numbers of visits to spaces, parks, or natural areas by tourists in the world are significant (Balmford et al., 2015). Specifically, Nel-Lo and Llanes (2016) indicate that $10 \%$ of world tourism is ecotourism and, in the case of Spain, near to 14.5 million people visited natural parks in 2016. Moreover, Spain has $13 \%$ of its territory with protected natural spaces (EUROPARC, 2016), a figure that increases if we consider the territories included in the Natura 2000 Network, being in this case $27 \%$ of the national territory.

\section{Literature Review}

\subsection{Ecotourism}

The emergence of ecotourism is taking shape hand in hand with three main reasons: the search for uncontaminated places, the need to 'flee' from large cities to develop the quality of life, growing awareness of environmental problems by people since the seventies, and the choice of new experiences in tourism (Toselli, 2014). Ecotourism, according to Weaver and Lawton (2002), appeared in AngloSaxon academic literature in the late 1980s and gained strength in later decades.
The ecotourism term, according to Jiménez Bulla (2009), appeared at the 1972 United Nations Conference on the Human Environment, at the same time that the term eco-development. Ecotourism is defined in the following terms: travel to visit relatively unaltered natural areas, including protected areas in order to enjoy, appreciate and study natural attractions (landscape, flora and wildlife), as well as any cultural manifestation of the present and past, through a process that promotes conservation, has low negative environmental and cultural impact, encourages active involvement and socioeconomic benefit of local communities (Ceballos-Lascurain, 1987 , p. 120), but there is still a lot of debate about how to define it (Cobbinah, 2015).

Sundström (2003) states that ecotourism originated in South America and the Caribbean, in the 1960s, in countries such as Costa Rica, Ecuador and Peru, because of the need to protect the biodiversity that inhabits the forest, which covers a large area in each of their territories, where, unfortunately, there has always been great interest on the part of non-local individuals to exploit for extractive purposes, mainly oil, or to build hydroelectric dams, affecting flora and fauna and other natural resources.

Puhakka and Siikamäki (2012) state that environmental concern for the sustainability of tourist destinations has increased in recent decades, helping the emergence of so-called sustainable tourism, which has conditioned the design of international public policies.

\subsection{Ecological Behaviour of the Tourist}

The study of the behaviour of consumers of ecological products and services is a subject of great interest (Fraj-Andrés \& Martínez-Salinas, 2007). The figure of the ecological consumer, therefore, has come to be present, understood as "the ecological consumer is generally defined as one who adopts behaviours and/or who buys ecological products over alternatives" (Boztepe, 2012, p. 7). Ecological behaviour has also been approached from different areas, such as recycling, adequate consumption or the payment an extra price for the consumption of ecological products (Hultman et al., 2015).

In order to understand the ecological behaviour of individuals, diverse factors are measured (Fraj-Andrés \& Martínez-Salinas, 2007) like as demographics, socioeconomic 
psychographics, environmental knowledge factors and cultural factors.

All of these factors can be linked to behaviour in favour of the natural environment, while at the same time influencing decisions to consume goods and services with less environmental impact (García de Leaniz et al., 2019). On this specificity, points out that ecological consumers are willing to change their states of life if this helps to care for the environment. Boztepe (2012) points out some features of ecological consumers, they have greater self-control, tolerant and less dogmatic, because they think that their behaviour is necessary in order to protect the environment, given that this work is not only of companies or governments. In this line, Millar et al. (2012) assessed the environmental attitudes of business and leisure travellers, their green behaviour at home, and the level of importance they place on having different green attributes in a hotel, whose results indicated that business and leisure travellers are very similar when rating the importance of specific green attributes.

\subsection{Models of Ecological Behaviour for Touristic Sector Model Value-Belief-Norm}

The value-belief-norm model (VBN) is a global model of psychological approach developed by Stern et al. (1999). The VBN is a hierarchical model that has its robustness in a successive chain of elements that, faced with an ecological or environmental problem, activate the immediately after in a direct way or not.

VBN theory is based on three previous theories: Schwartz values theory (Schwartz \& Bilsky, 1987); the normative influence model (NIM) (Schwartz, 1977); and the New Environmental Paradigm (NEP) (Van Liere \& Dunlap, 1978). From the first theory, it adopts the traditional conception of values as principles that guide the development of attitudes; from the NAM model, the explanation of the mechanism that drives individuals to adopt altruistic behaviours; and from the NEP, the social conscience about the effect of human action on the biosphere or environmental vision of the world.

According to Choi et al. (2015), the VBN model is a theory that creates a conceptual framework based on several components: values, beliefs, norms and behaviours. Among the values, we find biospheric, altruistic and selfish values.

The VBN model has been used in tourism on consumption in ecological hotels (Choi et al., 2015; Han, 2015), in environmental behaviour of young travellers (Kiatkawsin \& Han, 2017), in recreational behaviour (Lee \& Jan, 2018), in pro-sustainable behaviours or in environmentally friendly services (Van Riper et al., 2020).

Therefore, based on previous research, the values that can affect to the ecotourism are biospheric, altruistic and selfish values. Among the beliefs there are three constructs: New Ecological Paradigm, sense of responsibility and awareness of consequences. And with regard to standards, personal standards stand out (Kiatkawsin \& Han, 2017).

\section{Theory of Planned Behavior}

The theory of planned behaviour (Ajzen, 1991) was born as an extension of the theory of reasoned action (Ajzen \& Fishbein, 1980) to overcome various aspects of this model and in order to understand the behaviours of individuals who do not always have voluntary control. The central factor of this theory is the intention to perform a behaviour, taking into account that in the intentions are the factors that motivate the behaviour. Therefore, there is the idea that the stronger the intention to perform a behaviour by the individual, the more likely it is to happen, but this only happens in controlled situations, since the roles of opportunities and resources are of interest to understand the behaviour of individuals.

The theory of planned behaviour has shown its usefulness because its object, through attitudes and beliefs, is the prediction and understanding of the way individuals behave. It is fully valid to know the intention and environmental behaviour of individuals since they are related to what they feel and think about the tourism sector (Li et al., 2019), in the field of the environment, such as the intention to pay an extra cost for doing ecotourism (Hultman et al., 2015).

\subsection{Research Hypotheses}

Part of the previous literature has opted in its research to work with biospheric values, given that it has been demonstrated that they influence the environmental attitude of behaviours (Han, 2015; Kiatkawsin \& Han, 2017) and encourage 
it, both in daily life and in tourist behaviour (Lee \& Jan, 2018). In that sense, to study the intentions to visit ecological hotels, following the perspective of intention as a conative component, that is, the intention to visit is a willingness to perform an action as an essential predictor or prior to a behaviour among U.S. students only used biospheric values, as a factor of interest in the VBN model (Choi et al., 2015), showing its utility and influence. Han (2015) indicates that biospheric values have a positive influence in relation to the visit to ecological lodgings and, in the same sense, individuals with high biospheric values have strong pro-environmental beliefs (Choi et al., 2015), showing consumption restriction behaviours.

Taking into account Chen's (2015) study on the application of the VNC model to predict pro-environmental behaviours, selfish, socialaltruistic and biospheric values positively influence environmental beliefs or the NEP. Therefore, based on the previous studies, we propose the following hypotheses:

H1: Biospheric values have a positive impact on the new ecological paradigm.

H2: Selfish values have a negative impact on the new ecological paradigm.

The environmental worldview or environmental beliefs, equated and operationalized through the New Ecological Paradigm scale (Han, 2015), possesses a predictive capacity in relation to ecological attitudes and behaviours Dunlap et al. (2000), which generates an NEP capacity to measure the awareness or impact of knowledge of human activity on the environment and how this affects human well-being. The validity of this scale, in relation to the measurement of the beliefs that drive pro-environmental behaviour, has been widely studied and corroborated (Stern et al., 1995). Normally, research indicates that the new ecological paradigm, within the framework of VNC theory, positively affects awareness of the consequences in the area of ecological behaviour, energy consumption or tourism (Choi et al., 2015; Han, 2015; Kiatkawsin \& Han, 2017; Stern et al., 1999).

For the immediately explained, we propose the following hypothesis:

H3: The new ecological paradigm has a positive impact on awareness of consequences.

Some research has pointed out the existence of a relationship between awareness of the consequences and allocation of responsibility in the field of tourism and responsible or green consumption (Choi et al., 2015; Kiatkawsin \& Han, 2017; Stern et al., 1995).

Wynveen et al. (2015) in their study related to populations living near marine areas of interest in Australia and the United States, where they applied the VBN model, show the positive relationship between consciousness of consequences, and ascription of responsibility, personal norm and intention of behaviour, for both the Australian and the North American sample.

Therefore, we propose the hypotheses related to the awareness of consequences:

H4: Awareness of consequences has a positive impact on the sense of responsibility.

H5: Awareness of consequences has a positive impact on personal norms.

H6: Awareness of consequences has a positive impact on the intention to do ecotourism.

Likewise, there are different studies that have pointed out the influence of the assignment of responsibility and personal rules using the VBN model (Choi et al., 2015; Kiatkawsin \& Han, 2017; Stern et al., 1999). Therefore, based on the previous studies, we propose the following hypothesis:

H7: Sense of responsibility has a positive impact on personal norms of ecotourists.

Kiatkawsin and Han (2017) stablish that the personal pro-environmental norms of tourists have a positive relationship with the intention to behave in an environmentally friendly way while traveling. Literature indicates that the person with strong personal norms has a greater willingness to visit and stay in an ecological hotel than those who do not (Han, 2015). Relative to ecological behaviour on cruise ships, Han (2015) carried out among 350 consumers in the United States, points to the positive relationship between personal norms, understood as the obligation that consumers have to take or do pro-environmental activities, and the intention to make a sacrifice, which points out, among others, the reference to the intention to pay more for a more ecological cruise.

Therefore, taking into account the studies proposed above, we propose the following hypotheses:

H8: Personal norms have a positive impact on the intention to do ecotourism. 
H9: Personal norms have a positive impact on the intention to pay an extra price for doing ecotourism.

Similarly, Han (2015), in his study on the factors that influence the environmental behaviour intentions of tourists staying in ecological spaces, points out that subjective names have a significant relationship with personal norms, as well as with behavioural intention.

Lee and Jan (2018) in their study on the behaviour of ecotourists in Taiwan, carried out among 136 questionnaires, use a model that mixes variables from different theories of social psychology, and the result obtained is that there is a significative relationship between personal norms and the intention of tourists to carry out ecotourism behaviours.

Therefore, taking into account the studies proposed above, we propose the following hypotheses:

H10: Social norms have a positive impact on personal norms.

H11: Social norms have a positive impact on the intention to do ecotourism.

In order to analyse the intention to pay a surcharge for visiting ecotourism sites, Hultman et al. (2015) used the post-materialistic theory and the theory of planned behaviour. This points out that there is a positive relationship between the intention to do ecotourism, through items referring to the intention to visit an ecotourism destination in the future, that even operative in a behavioural intention in favour of a visit to an ecotourism destination in less than twelve months, and the intention to pay more for enjoying your trip or vacation in favour, for example, of pollution reduction, conservation of the natural environment, or for differentiation in relation to usual tourism. Based on these investigations, we formulate the following hypothesis:

H12: The intention to do ecotourism has a positive impact on the intention to pay more for doing ecotourism.

\section{Methods}

According to the theoretical framework studied, we have developed a questionnaire based on the scales of interest, which has been assessed by specialists and through a pre-test carried out in Spain. Subsequently, this questionnaire has been corrected taking into account the contributions of the pre-test and of those specialists consulted, in order to improve the indices of reliability, validity and homogeneity of the items.

This research was based on online questionnaire carried out in Spain, among ecotourists more than 15 years old, during the third quarter of 2017, by an online marketing research company. The sample size was 403 questionnaires, carried out through a simple random sample, given that the population is higher than 100,000 . The $51.7 \%$ of the sample are man and $48.3 \%$ are woman. Regarding the age, the $20.50 \%$ are between 15 and 30 , the $33.1 \%$ between 31 and 44 , the $35.2 \%$ between 45 and 64 , and the $11.3 \%$ more than 64 years old. The scales used in our research were based on previous studies and measured by multiple items five-point Likert scales. For measuring biospheric values and selfish values we based on Han (2015) and Kiatkawsin and Han (2017); for new ecological paradigm we based on Dunlap et al. (2000); for awareness of consequences we based on Han (2015) and Kiatkawsin and Han (2017); for sense of responsibility we used Kiatkawsin and Han (2017); for personal norms Choi et al. (2015); for social norms Han (2015); for intention to do ecotourism and for intention to pay more for ecotourism we based Lu et al. (2016) and Hultman et al. (2015); and for intention to pay more for ecotourism.

For the treatment and analysis of the data provided by the questionnaires, different informative packages have been used: the SPSS v. $22^{\circledR}$ software to carry out the descriptive analysis and the reliability of the scales and through the Smart PLS 3.6.2 ${ }^{\circledR}$ software, to analyse the conceptual model through structural equations modelling.

A structural equation modelling (SEM), specifically consistent partial least squares (cPLS), is proposed to test the proposed hypotheses. We have used this technique because is more appropriate for exploratory research (Fornell \& Bookstein, 1982), and because the cPLS algorithm shows greater convergence in its simplicity, offering fewer restrictions on data normality (Chin et al., 2003). Specifically, for common factor (reflective) models, it is appropriated to apply cPLS because it uses a correction to obtain consistent estimates in models where the underlying constructs are modelled by means 
of common factors (Sarstedt et al., 2016).

SmartPLS 3.6.2 software was used to analyse the data (Ringle et al., 2017). The stability of the estimates was tested via a bootstrap re-sampling procedure $(2,500$ subsamples).

\section{Results}

A cPLS model is analysed in two stages: First, the assessment of the reliability and validity of the measurement model, and second, the assessment of the structural model (Chin et al., 2003).

\subsection{Reliability and Validity Assessment}

Tab. 1 displays the analysis results of reliability and convergent validity. Convergent validity is verified by analysing the factor loadings and their significance. In the case of the New Ecological Paradigm are lower, so we rescued the items $(2,3,5,7,8,10,12,13,15)$, whose values are higher than 0.5 , following to Urbach and Ahlemann (2010). On the other hand, altruistic value's items were not valid and reliability, so this construct was removed of our final model. Finally, the individual item loadings in our model are higher than 0.5 , and the average of the item-to-factor loadings are higher than 0.7 (Hair et al., 2006). Also, we have checked the significance of the loadings with a re-sampling procedure (2,500 sub-samples) for obtaining t-statistic values. They are all significant $(p<0.001)$. This finding provides evidence supporting the convergent validity of the indicators (Anderson \& Gerbing, 1988).

On the other hand, the Cronbach's alpha and composite reliability ensure the reliability of scales. All Cronbach's alpha scores in this study were above the recommended value of 0.7 for scale robustness (Nunnally, 1978). Composite reliabilities in the proposed model exceeded the threshold of 0.7 recommended by Nunnally (1978). Moreover, average variance extracted (AVE) was also calculated for each construct, resulting in AVEs greater than 0.5 (Fornell \& Larcker, 1981), except for NEP scale.

\section{Tab. 1: Internal consistency and convergent validity - Part 1}

\begin{tabular}{|c|c|c|c|c|c|}
\hline \multicolumn{2}{|c|}{ Constructs } & Factor loading* & AVE & $\alpha$ & CR \\
\hline \multirow[t]{4}{*}{ Biospheric values } & BV1 & 0.87 & \multirow{4}{*}{0.73} & \multirow{4}{*}{0.88} & \multirow{4}{*}{0.92} \\
\hline & BV2 & 0.87 & & & \\
\hline & BV3 & 0.89 & & & \\
\hline & BV4 & 0.79 & & & \\
\hline \multirow[t]{4}{*}{ Selfish values } & SV1 & 0.83 & \multirow{4}{*}{0.75} & \multirow{4}{*}{0.89} & \multirow{4}{*}{0.92} \\
\hline & SV2 & 0.90 & & & \\
\hline & SV3 & 0.91 & & & \\
\hline & SV4 & 0.83 & & & \\
\hline \multirow[t]{9}{*}{ New ecological paradigm } & NEP2 & 0.63 & \multirow{9}{*}{0.40} & \multirow{9}{*}{0.81} & \multirow{9}{*}{0.86} \\
\hline & NEP3 & 0.55 & & & \\
\hline & NEP5 & 0.69 & & & \\
\hline & NEP7 & 0.67 & & & \\
\hline & NEP8 & 0.65 & & & \\
\hline & NEP10 & 0.69 & & & \\
\hline & NEP12 & 0.67 & & & \\
\hline & NEP13 & 0.52 & & & \\
\hline & NEP15 & 0.65 & & & \\
\hline
\end{tabular}




\section{Marketing and Trade}

Tab. 1: Internal consistency and convergent validity - Part 2

\begin{tabular}{|c|c|c|c|c|c|}
\hline \multicolumn{2}{|l|}{ Constructs } & Factor loading* & AVE & $\alpha$ & CR \\
\hline \multirow[t]{8}{*}{ Awareness of consequences } & $A C 1$ & 0.86 & \multirow{8}{*}{0.76} & \multirow{8}{*}{0.96} & \multirow{8}{*}{0.96} \\
\hline & AC2 & 0.89 & & & \\
\hline & AC3 & 0.89 & & & \\
\hline & AC4 & 0.86 & & & \\
\hline & AC5 & 0.88 & & & \\
\hline & AC6 & 0.87 & & & \\
\hline & AC7 & 0.87 & & & \\
\hline & AC8 & 0.85 & & & \\
\hline \multirow[t]{3}{*}{ Sense of responsibility } & SR1 & 0.72 & \multirow{3}{*}{0.63} & \multirow{3}{*}{0.71} & \multirow{3}{*}{0.83} \\
\hline & SR2 & 0.80 & & & \\
\hline & SR3 & 0.84 & & & \\
\hline \multirow[t]{6}{*}{ Personal norms } & PN1 & 0.69 & \multirow{6}{*}{0.56} & \multirow{6}{*}{0.84} & \multirow{6}{*}{0.88} \\
\hline & PN2 & 0.82 & & & \\
\hline & PN3 & 0.70 & & & \\
\hline & PN4 & 0.79 & & & \\
\hline & PN5 & 0.79 & & & \\
\hline & PN6 & 0.66 & & & \\
\hline \multirow[t]{3}{*}{ Social norms } & SN1 & 0.94 & \multirow{3}{*}{0.89} & \multirow{3}{*}{0.94} & \multirow{3}{*}{0.96} \\
\hline & SN2 & 0.95 & & & \\
\hline & SN3 & 0.94 & & & \\
\hline \multirow[t]{4}{*}{ Intention to do ecotourism } & IDE1 & 0.83 & \multirow{4}{*}{0.69} & \multirow{4}{*}{0.85} & \multirow{4}{*}{0.90} \\
\hline & IDE2 & 0.76 & & & \\
\hline & IDE3 & 0.88 & & & \\
\hline & IDE4 & 0.83 & & & \\
\hline \multirow{7}{*}{$\begin{array}{l}\text { Intention to pay more for } \\
\text { ecotourism }\end{array}$} & IPME1 & 0.72 & \multirow{7}{*}{0.69} & \multirow{7}{*}{0.92} & \multirow{7}{*}{0.94} \\
\hline & IPME2 & 0.82 & & & \\
\hline & IPME3 & 0.82 & & & \\
\hline & IPME4 & 0.71 & & & \\
\hline & IPME5 & 0.89 & & & \\
\hline & IPME6 & 0.88 & & & \\
\hline & IPME7 & 0.89 & & & \\
\hline
\end{tabular}

Note: *p-value $<0.05 ;$ AVE = average variance extracted; $\alpha=$ Cronbach's alpha; $C R=$ composite reliability. 
On the other hand, this research adopted the classic Fornell and Larcker (1981) criteria of discriminant validity to examine whether the square root of the AVE for each construct exceeds the correlation shared between the construct and other constructs in the model. As shown in Tab. 2, all diagonal values exceeded the inter-construct correlations, thereby demonstrating adequate discriminant validity of all constructs, except with the NEP dimension. It is questioned whether it can share more variance with the construct biospheric values than with its own indicators, due to the similarity of its measurement items. Nevertheless, following to classic crossing load criteria, no item charges more strongly on another construct than on that construct it tries to measure. In turn, each construct (NEP, in this case) charges more on its assigned indicators than on other items (Gefen \& Straub, 2005). Moreover, following third discriminant validity criteria stablish by Henseler et al. (2015), ratio heterotrait-monotrait (HTMT), bootstrap confidence interval at $90 \%$ of the HTMT ratio does not include the value 1 . In sum, all constructs of the model reach discriminant validity.

\subsection{Structural Model}

To assess the predictive ability of the structural model we followed the approach proposed by Falk and Miller (1992) that the $R^{2}$ value (variance accounted for) of each of the dependent constructs exceed the 0.1 value. Tab. 3 shows that the $R^{2}$ values in the dependent variables are higher than the critical level mentioned. Another test applied was the Stone-Geisser test of predictive relevance $\left(Q^{2}\right)$. This test can be used as an additional assessment of model fit in PLS analysis (Geisser, 1975). Models with $\mathrm{Q}^{2}$ greater than zero are considered to have predictive relevance (Chin, 1998). In our case $\mathrm{Q}^{2}$ is positive for all predicted variables.

Related to the global adjustment indicators, the Goodness of Fit index (GoF) has been also analysed. The values of this statistic fluctuate between 0 and 1 , being an optimal stage that are higher than 0.31 (Chin, 1998). It indicates that the global adjustment of model would show a certain quality. It means good adjustment of the model proposed.

Next, in Tab. 3 it is showed the summary of the hypothesis testing.

Fig. 1 shows a synthesis of the results obtained. Bootstrapping (2,500 re-samples) was used to generate t-values. Support for each general hypothesis can be determined by examining the sign and statistical significance of the t-values.

The results of these twelve proposed hypotheses allow us to point out that biospheric values have a positive and significant impact on the New Ecological Paradigm ( $\beta=0.55$; $p<0.01$ ), and selfish values have a negative impact $(\beta=-0.28 ; p<0.01)$. Therefore, $H 1$ and $H 2$ are supported.

\section{Tab. 2: Discriminant validity of the theoretical construct measured}

\begin{tabular}{l|c|c|c|c|c|c|c|c|c} 
& SR & AC & IDE & IPME & NEP & PN & SN & BV & SV \\
\hline SR & 0.67 & & & & & & & & \\
\hline AC & 0.41 & 0.76 & & & & & & & \\
\hline IDE & 0.28 & 0.33 & 0.69 & & & & & & \\
\hline IPME & 0.32 & 0.27 & 0.52 & 0.69 & & & & & \\
\hline NEP & 0.36 & 0.69 & 0.34 & 0.25 & 0.40 & & & & \\
\hline PN & 0.44 & 0.51 & 0.49 & 0.54 & 0.50 & 0.55 & & & \\
\hline SN & 0.27 & 0.20 & 0.35 & 0.54 & 0.12 & 0.54 & 0.89 & & \\
\hline BV & 0.41 & 0.59 & 0.37 & 0.31 & 0.60 & 0.53 & 0.24 & 0.73 & \\
\hline SV & -0.09 & -0.19 & -0.01 & 0.09 & -0.37 & -0.01 & 0.19 & -0.16 & 0.75 \\
\hline
\end{tabular}

Source: own

Note: Diagonal elements are the square root of average variance extracted (AVE) between the constructs and their measures. Off diagonal elements are correlations between constructs. 


\section{Marketing and Trade}

\section{Tab. 3: Structural model results}

\begin{tabular}{c|l|c|c|c} 
& \multicolumn{1}{|c|}{ Hypothesis } & $\begin{array}{c}\text { Original } \\
\text { sample }\end{array}$ & $\begin{array}{c}\text { Std. } \\
\text { deviation }\end{array}$ & T-statistics \\
\hline H1 & Biospheric value $\rightarrow$ NEP & 0.55 & 0.04 & $12.79^{* * *}$ \\
\hline H2 & Selfish value $\rightarrow$ NEP & -0.28 & 0.05 & $5.44^{* * *}$ \\
\hline H3 & NEP $\rightarrow$ Awareness of consequences & 0.69 & 0.03 & $21.64^{* * *}$ \\
\hline H4 & Awareness of consequences $\rightarrow$ Sense of responsibility & 0.41 & 0.06 & $7.15^{* * *}$ \\
\hline H5 & Awareness of consequences $\rightarrow$ Personal norms & 0.35 & 0.05 & $7.60^{* * *}$ \\
\hline H6 & $\begin{array}{l}\text { Awareness of consequences } \rightarrow \text { Intention to } \\
\text { do ecotourism }\end{array}$ & 0.12 & 0.06 & $1.94^{*}$ \\
\hline H7 & Sense of responsibility $\rightarrow$ Personal norms & 0.19 & 0.05 & $3.44^{* * *}$ \\
\hline H8 & Personal norms $\rightarrow$ Intention to do ecotourism & 0.36 & 0.07 & $5.36^{* * *}$ \\
\hline H9 & Personal norms $\rightarrow$ Intention to pay more & 0.43 & 0.06 & $7.60^{* * *}$ \\
\hline H10 & Social norms $\rightarrow$ Personal norms & 0.42 & 0.04 & $9.32^{* * *}$ \\
\hline H11 & Social norms $\rightarrow$ Intention to do ecotourism & 0.13 & 0.07 & $1.97^{* *}$ \\
\hline H12 & Intention to do ecoutourism $\rightarrow$ Intention to pay more & 0.31 & 0.06 & $5.26^{* * *}$ \\
\hline
\end{tabular}

Note: $R^{2}$ values: $R^{2}(N E P): 0.43 ; R^{2}(A C): 0.47 ; R^{2}(S R): 0.17 ; R^{2}(P N): 0.48 ; R^{2}(I D E): 0.26 ; R^{2}(I P M E): 0.41$.

* Sig. $10 \%$; ${ }^{* *}$ Sig. $5 \%$; ${ }^{* *}$ Sig. $1 \%$.

\section{Fig. 1: Research model}

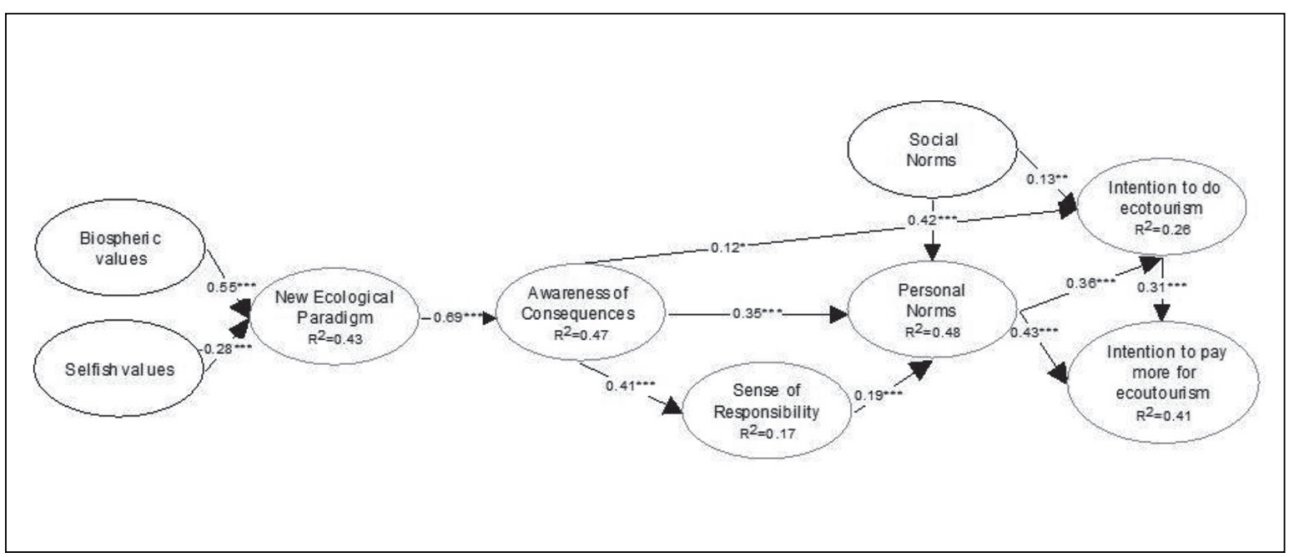

Source: own 
The New Ecological Paradigm has a positive and significant impact on the awareness of the consequences $(\beta=0.69 ; p<0.01)$, supporting $H 3$.

In addition, the results obtained allow us to point out that awareness of the consequences has a positive and significant impact with the sense of responsibility $(\beta=0.41 ; p<0.01)$, on personal norms $(\beta=0.35 ; p<0.01)$, and on the intention to do ecotourism $(\beta=0.12 ; p<0.1)$. Therefore H4, $\mathrm{H} 5$ and $\mathrm{H} 6$ are supported, although the last one is only significant at $10 \%$ level.

The sense of responsibility has a positive influence on the personal norms of ecotourists $(\beta=3.44 ; p<0.01)$. In that respect $H 7$ is supported.

Personal norms have a positive and significant impact on the intention to do ecotourism $(\beta=0.36 ; p<0.01)$ and on the intention to pay more for doing ecotourism $(\beta=0.43 ; p<0.01)$. So, $H 8$ and $H 9$ are supported.

Social norms have a positive and significant impact on personal norms $(\beta=0.42 ; p<0.01)$ and on the intention to do ecotourism $(\beta=0.13$; $p<0.05)$. Therefore, we support the hypotheses $H 10$ and $H 11$.

Finally, the intention to do ecotourism has a positive and significant impact on the intention to pay more for doing this type of alternative tourism $(\beta=0.31 ; p<0.01)$. Therefore, $H 12$ is supported.

The above results indicate that the proposed model explain the consumer behaviour of ecotourist in Spain.

\section{Discussion}

Tourism is one of the main economic industries worldwide, although significant changes have been taking place due to the shift from mass tourism to alternative tourism that respects the environment and where the tourist acquires new experiences in contact with nature, culture, and the residents of a territory. In recent years, new, more sustainable forms of tourism have appeared, where there are elements related to rest, enjoyment and protection of the environment or knowledge of the local culture, through policies that favour sustainable development, mainly because society is becoming increasingly aware of the negative impacts on nature, both for economic and cultural and social reasons.

At present, there are new forms of tourism, which appeared once the symptoms of the exhaustion of mass tourism were evident. The so-called alternative tourism became established and, among them, ecotourism emerged strongly. In the same sense, the tourist consumer points out the peremptory necessity of tourism as a way of life, where natural cultural values and environmental concern are present in the decision-making process of purchasing tourism products (Manrai \& Manrai, 2011).

Monteiro et al. (2015) point out that, in the 1960s, ecological awareness awoke, giving way to an era of action since the 1970s and 1980s where environmental awareness increased. Environmental concern has evolved from the sixties with the themes of energy conservation or pollution in developed countries, as well as in the nineties, through the 'decade of the environment' to the present day, where there is a greater number of consumers who have assumed the ecological points in decisionmaking and consumption.

In the same line, Beaumont (2011) notes that the concept of ecotourism has evolved mainly two aspects: First, focusing on ideas of nature and learning and, second, describing what ecotourists do on their holidays. In this line, Stylos and Vassiliadis (2015) focus their research on capturing the perceptions and practices of hotel management in respect to the concept of three-dimensional sustainability whose findings suggest that hotel star ratings play a significant role in the perceived importance of financial measures of economic viability, as well as in the application of socially responsible practices by hotel management. As main conclusion, it was found that hotel location does not play a significant role in shaping perceptions of sustainability dimensions.

In sum, ecotourists and their proenvironmental or ecological behaviour is an area with research opportunities to know the factors that determine it, whether economic, cultural, social, demographic or psychographic (Hultman et al., 2015; Kiatkawsin \& Han, 2017). Only later were new criteria incorporated, in addition to aspects such as environmental responsibility, although this is a more academic and government discussion. These new criteria are associated with sustainability, conservation, use of natural resources and respect for communities.

The concern for the environment, of interest both for academia and for the business sector and for society in general, has been translated 
in the last decades in the emergence of the socalled green or green Marketing. The care for the environment can influence on the behaviour of consumers from a general point of view, and tourists in particular. The academia finds it necessary to know what factors, whether internal or external to the consumer behaviour, influence their purchasing behaviour of ecological or natural products or services, which in the tourism field materialize in a new form of alternative tourism, whether through nature tourism or ecotourism (Hultman et al., 2015).

The literature review has facilitated the identification of models and variables that are of interest to understand the ecological behaviour of ecotourists, among which the theory of planned behaviour and the value-belief-norm model stand out.

The theory of planned behaviour (Ajzen, 1991) was born as an extension of the theory of reasoned action (Ajzen \& Fisbein, 1980) and to understand the behaviours of individuals who do not always have voluntary control. The central factor of this theory is the intention to perform a behaviour, considering that intentions are the factors that motivate behaviour.

The value-belief-norm model developed by Stern et al. (1999), which is based on three previous theories: Schwartz's Value theory (Schwartz \& Bilsky, 1987), the normative influence model (Schwartz, 1977) and the New Environmental Paradigm (Van Liere \& Dunlap, 1978), is a theoretical formulation based on beliefs about man's ability to modify the environmental balance, growth, and the right of mankind to govern the rest of nature. This theory was operationalized through a Likert scale with several items. This model is shaped by values, beliefs, norms, and behaviours (Choi et al., 2015).

\section{Conclusion}

Based on previous literature, specifically on value-belief-norm model (Stern et al., 1999) and theory of planned behaviour (Ajzen, 1991), we have proposed a global model relative to study of the causal relationships between of composed constructs classified in four typologies: personal values (biospheric and selfish values); believes (NEP, awareness of consequences and sense of responsibility); norms (personal and social norms); and behavioural intention towards ecotourism (pay more; to do ecotourism). These measurements were analysed by PLS-SEM methodology, in order to verify the global model applied to Spanish ecotourists. In that process, the results facilitate knowledge of the importance of each construct and how they relate to each other.

Specifically, results indicate positive effect from only one personal value (i.e., biospheric value) to environmental beliefs (i.e., new ecological paradigm), and negative influence from other personal value (i.e., selfish value) to them. The first effect is higher compared with the rest of casual relationships of general model. It could be caused because ecotourist population consider very important aspects such as protection of the environment, preservation of nature, etc. In consequence, these values cause direct effect on beliefs related to new ecological paradigm like human are severely abusing the environment, the balance of nature is very delicate and easy to disturb, the balance of nature is strong enough to adjust to the impacts of modern industrial countries, etc. On the other hand, selfish values have little negative effect on environmental attitudes, due to be dominant with others, wealth and have material possessions are contrary characteristics to items which compose the N.E.P.

It is important to point out the importance of relationship between new ecological paradigm and awareness of consequences. It is a strong relation of the model. It may be because environmental beliefs (e.g., plants and animals have as much right to exist as human, if things continue as they are now, human will experiment a major ecological catastrophe, etc) directly affect on individuals' consideration towards environment (e.g., beliefs about toxic substances in the air, water and soil are very serious problem for the country, family and other species such as plants and animals, beliefs about climate change and loss of forest are very serious problems for all of them).

There is high influence between awareness of consequences and sense of responsibility, due to the first elements - above indicated directly affect on the belief relative to each tourist is responsible for the environmental deterioration caused by each trip.

Intention to do ecotourism is positively influenced by one belief (awareness of consequences) and the two norms included in the model (i.e., personal and social norms). Aspects related to beliefs about ecological thoughts - above indicated -, as well as individuals' intrinsic and extrinsic characteristics 
(e.g., feel morally obligated to use a green hotel, feel compelled the environment and nature when they travel, feel personally obliged to save as much energy as possible - personal norms and take into account opinions of other people about the advantages of doing ecotourism social norms -). In turn, this last construct (i.e., intention to do ecotourism) and personal norms have positive influence on intention to pay more for doing ecotourism.

In sum, obtained results facilitate the understanding of how tourists manage their values, beliefs and attitudes in relation to the realization of ecotourism practices.

Businesses and institutions working in the sustainable tourism environment can use our results to try to influence the attitudes and the intention of tourists with marketing plans to engage in ecotourism, thereby improving marketing and thematising products. In this sense, it is necessary to design ecotourism products that provide tourists with a wide range of services on their trip. Similarly, actions should be taken to promote the values of ecotourism in Spain, on how it can help municipalities and their natural spaces, with a view to sustainability for future generations. It is also of interest to make efforts to disseminate the strengths of ecotourism, to facilitate their knowledge and understanding by citizens. To this end, it is necessary to make a special effort in those sectors of the population that do ecotourism or ecotourism in a more unequal way, as well as those that present weaker social and environmental values, but that show an attitude of doing nature tourism and behaving ecologically. Based on the results, organizations can use them to carry out activities that improve ecological tourism products, their trade, and their dissemination. Similarly, it is of interest to work on the dissemination of content that reinforces the idea that the performance of ecological behaviours serves to reduce the impacts that tourist activities have on the environment. These practices can favour and help the environments where ecotourism takes place to conserve, maintain and protect their biological diversity more effectively.

Finally, there are some limitations in this work. On the one hand, we have worked in a single country so it may be of interest to make comparisons between different countries to conduct cross-cultural studies. Similarly, we have investigated those who consider themselves ecotourists but, perhaps, it would be interesting to study the population to make tourism in general in relation to their ecological behaviour.

On the other hand, we have worked with the ideas of the intention of doing ecotourism and the intention of paying more for it. As future research line, it would be possible to carry out this study with specific activities or consumption in the ecotourism field, such as ecotourism activities (environmental education activities), knowledge of quality seals, etc. Moreover, would be interesting to develop a segmentation of ecotourist sample based on their economic and socio-demographic characteristics related to more important constructs in the model analysed (e.g., new ecological paradigm). Finally, we are comparing this global model in two different countries, using different moderator variables such as cultural values, age and gender.

\section{References}

Ajzen, I. (1991). The theory of planned behavior. Organizational Behavior and Human Decision Processes, 50(2), 179-211. https:// doi.org/10.1016/0749-5978(91)90020-t

Ajzen, I., \& Fishbein, M. (1980). Attitudes and the Attitude-Behavior Relation: Reasoned and Automatic Processes. Hoboken, $\mathrm{NJ}$ : Prentice-Hall.

Anderson, J. C., \& Gerbing, D. W. (1988). Structural equation modeling in practice: A review and recommended two-step approach. Psychological Bulletin, 103(3), 411-423. https://doi.org/10.1037/0033-2909.103.3.411

Balmford, A., Green, J. M. H., Anderson, M., Beresford, J., Huang, C., Naidoo, R., Walpole, M., \& Manica, A. (2015). Walk on the wild side: Estimating the global magnitude of visits to protected areas. PLoS Biology, 13(2), e1002074. https://doi.org/10.1371/journal.pbio.1002074

Beaumont, N. (2011). Ecotourism: Impacts, potentials and possibilities. Annals of Leisure Research, 14(4), 390-392. https://doi.org/10.1 080/11745398.2011.639443

Boztepe, A. (2012). Green marketing and its impact on consumer buying behavior. European Journal of Economic and Political Studies, 5, 5-21.

Ceballos-Lascurain, H. (1987). Estudio de perfectibilidad socioeconómica del turismo ecológico y anteproyecto arquitectónico $y$ urbanístico del centro de turismo ecológico 
de San Kalan, Quintana Roo [Socio-economic perfectibility study of ecotourism and preliminary architectural and urban development project of the ecotourism centre of San Kalan, Quintana Roo]. México: SEDUE.

Chen, M. F. (2015). An examination of the value-belief-norm theory model in predicting pro-environmental behaviour in Taiwan. Asian Journal of Social Psychology, 18(2), 145-151. https://doi.org/10.1111/ajsp.12096

Chin, W. W. (1998). The Partial Least Squares Approach for Structural Equation Modeling. In G. A. Marcoulides (Ed.), Modern Methods for Business Research (pp. 295-336). Mahwah, NJ: Lawrence Erlbaum Associates.

Chin, W. W., Marcolin, B. L., \& Newsted, P. R. (2003). A Partial Least Squares Latent Variable Modeling Approach for Measuring Interaction Effects: Results from a Monte Carlo Simulation Study and an ElectronicMail Emotion/Adoption Study. Information Systems Research, 14(2), 189-217. https://doi. org/10.1287/isre.14.2.189.16018

Choi, H., Jang, J., \& Kandampully, J. (2015). Application of the extended VBN theory to understand consumers' decisions about green hotels. International Journal of Hospitality Management, 51, 87-95. https://doi. org/10.1016/j.ijhm.2015.08.004

Cobbinah, P. B. (2015). Contextualising the meaning of ecotourism. Tourism Management Perspectives, 16, 179-189. https://doi. org/10.1016/j.tmp.2015.07.015

Dunlap, R. E., Van Liere, K. D., Mertig, A. G., \& Jones, R. E. (2000). New Trends in Measuring Environmental Attitudes: Measuring Endorsement of the New Ecological Paradigm: A Revised NEP Scale. Journal of Social Issues, 56(3), 425-442. https://doi.org/10.1111/00224537.00176

EUROPARC. (2016). EUROPARC-España: Anuario 2016 del estado de las áreas protegidas en España [EUROPARC-Spain: 2016 yearbook of the state of protected areas in Spain]. Madrid: EUROPARC. Retrieved from http:// www.redeuroparc.org/system/files/shared/ Publicaciones/Anuario_2016/anuario_2016_ europarc-espana.pdf

Falk, R. F., \& Miller, N. B. (1992). A Primer for Soft Modeling. Akron, $\mathrm{OH}$ : University of Akron Press.

Fornell, C., \& Bookstein, F. L. (1982). Two Structural Equation Models: LISREL and PLS Applied to Consumer Exit-Voice Theory. Journal of Marketing Research, 19(4), 440-452. https:// doi.org/10.1177/002224378201900406

Fornell, C., \& Larcker, D. F. (1981). Evaluating Structural Equation Models with Unobservable Variables and Measurement Error. Journal of Marketing Research, 18(1), 39-50. https://doi. org/10.1177/002224378101800104

Fraj-Andrés, E., \& Martínez-Salinas, E. (2007). Impact of Environmental Knowledge on Ecological Consumer Behaviour: An Empirical Analysis. Journal of International Consumer Marketing, 19(3), 73-102. https:// doi.org/10.1300/j046v19n03_05

García de Leaniz, P. M. G., Crespo, Á. H., \& Gómez-López, R. (2019). The role of environmental CSR practices on the formation of behavioral intentions in a certified hotel context: Exploring the moderating effect of customer involvement in the buying process. Spanish Journal of Marketing - ESIC, 23(2), 205-226. https://doi.org/10.1108/SJME-10-2018-0044

Gefen, D., \& Straub, D. (2005). A Practical Guide to Factorial Validity Using PLSGraph: Tutorial and Annotated Example. Communications of the Association for Information Systems, 16, 91-109. https://doi. org/10.17705/1cais.01605

Geisser, S. (1975). The Predictive Sample Reuse Method with Applications. Journal of the American Statistical Association, 70(350), 320-328. https://doi.org/10.1080/01621459.19 75.10479865

Hair, J. F., Black, W. C., Babin, B. J.,Anderson, R. E., \& Tatham, R. L. (2006). Multivariate Data Analysis. Hoboken, NJ: Prentice-Hall.

Han, H. (2015). Travelers' proenvironmental behavior in a green lodging context: Converging value-belief-norm theory and the theory of planned behavior. Tourism Management, 47, 164-177. https://doi. org/10.1016/j.tourman.2014.09.014

Henseler, J., Ringle, C. M., \& Sarstedt, M. (2015). A new criterion for assessing discriminant validity in variance-based structural equation modeling. Journal of the Academy of Marketing Science, 43(1), 115-135. https://doi. org/10.1007/s11747-014-0403-8

Hultman, M., Kazeminia, A., \& Ghasemi, V. (2015). Intention to visit and willingness to pay premium for ecotourism: The impact of attitude, materialism, and motivation. Journal of Business Research, 68(9), 1854-1861. https://doi.org/10.1016/j.jbusres.2015.01.013 
Hwang, J., Kim, W., \& Kim, J. J. (2020). Application of the value-belief-norm model to environmentally friendly drone food delivery services: The moderating role of product involvement. International Journal of Contemporary Hospitality Management, 32(5), 1775-1794. https://doi.org/10.1108/ IJCHM-08-2019-0710

Jiménez Bulla, L. H. (2009). Ecoturismo: Oferta y desarrollo sistémico regional [Ecotourism: Supply and regional systemic development]. Bogota: Ecoe Ediciones.

Kiatkawsin, K., \& Han, H. (2017). Young travellers' intention to behave proenvironmentally: Merging the value-beliefnorm theory and the expectancy theory. Tourism Management, 59, 76-88. https://doi. org/10.1016/j.tourman.2016.06.018

Lee, T. H., \& Jan, F. H. (2018). Ecotourism Behavior of Nature-Based Tourists: An Integrative Framework. Journal of Travel Research, 57(6), 792-810. https://doi. org/10.1177/0047287517717350

Li, H., Zhang, X., Streimikiene, D., \& Hipters, Z. (2019). How Does Work Pressure Moderate the Formation Mechanism of Revisit Intention of Leisure Tourism Destinations: A Test of Moderating Effect. E\&M Economics and Management, 22(3), 154-167. https://doi. org/10.15240/tul/001/2019-3-010

López Miguens, J. L., Álvarez González, P., \& González Vázquez, E. (2015). Conocimiento, valores e intenciones como determinantes del comportamiento ecológico. Revista Internacional de Sociología, 73(3), e018. https://doi.org/10.3989/ris.2015.73.3.e018

Manrai, L. A., \& Manrai, A. K. (2011). Hofstede's cultural dimensions and tourist behaviors: A review and conceptual framework. Journal of Economics, Finance and Administrative Science, 16(31), 23-48.

Millar, M., Mayer, K. J., \& Baloglu, S. (2012). Importance of Green Hotel Attributes to Business and Leisure Travelers. Journal of Hospitality Marketing \& Management, 21(4), 395-413. https://doi.org/10.1080/19368623.2012.624294

Monteiro, T. A., Giuliani, A. C., CavazosArroyo, J., \& Pizzinatto, N. K. K. (2015). Mezcla del marketing verde: Una perspectiva teórica [Mix of green marketing: A theoretical perspective]. Cuadernos del CIMBAGE, 17, 103-126.

Nel-Lo, M., \& Llanes, C. (2016). Ecoturismo. Barcelona: Universitat Oberta de Catalunya.
Nunnally, J. C. (1978). Psychometric Theory. New York, NY: McGraw-Hill.

Puhakka, R., \& Siikamäki, P. (2012). Nature tourists' response to ecolabels in Oulanka PAN park, Finland. Journal of Ecotourism, 11(1), 56-73. https://doi.org/10.1080/14724049.2011 .647917

Ringle, C. M., Wende, S., \& Will, A. (2017). SmartPLS 2.0 (beta). http://Www.Smartpls.De

Sarstedt, M., Hair, J. F., Ringle, C. M., Thiele, K. O., \& Gudergan, S. P. (2016). Estimation issues with PLS and CBSEM: Where the bias lies! Journal of Business Research, 69(10), 3998-4010. https://doi.org/10.1016/j. jbusres.2016.06.007

Schwartz, S. H. (1977). Normative Influences on Altruism. Advances in Experimental Social Psychology, 10, 221-279. https://doi.org/10.1016/s0065-2601(08)603585

Schwartz, S. H., \& Bilsky, W. (1987). Toward a universal psychological structure of human values. Journal of Personality and Social Psychology, 53(3), 550-562. https://doi. org/10.1037/0022-3514.53.3.550

Stern, P. C., Dietz, T., Abel, T., Guagnano, G. A., \& Kalof, L. (1999). Value-Belief-Norm Theory of Support for Social Movements: The Case of Environmentalism. Human Ecology Review, 6(2), 81-97.

Stern, P. C., Kalof, L., Dietz, T., \& Guagnano, G. A. (1995). Values, Beliefs, and Proenvironmental Action: Attitude Formation toward Emergent Attitude Objects. Journal of Applied Social Psychology, 25(18), 1611-1636. https://doi.org/10.1111/j.1559-1816.1995. tb02636.x

Stylos, N., \& Vassiliadis, C. (2015). Differences in Sustainable Management between Four- and Five-Star Hotels Regarding the Perceptions of Three-Pillar Sustainability. Journal of Hospitality Marketing \& Management, 24(8), 791-825. https://doi.org/10.1080/193686 23.2015.955622

Sundström, S. (2003). El ecoturismo como instrumento para desarrollo sostenible: Un estudio comparativo de campo entre Suecia y Ecuador. Karlstads: Karlstads Universitet, Institutionen för Kultur och Kommunikation.

Toselli, C. (2014). Turismo ecológico: Aspectos generales sobre esta nueva tendencia. Signos Universitarios, 12(24), 97-108.

Urbach, N., \& Ahlemann, F. (2010). Structural Equation Modeling in Information 


\section{Marketing and Trade}

Systems Research Using Partial Least Squares. Journal of Information Technology Theory and Application, 11(2), 5-40.

Van Liere, K. D., \& Dunlap, R. E. (1978). Moral Norms and Environmental Behavior: An Application of Schwartz's Norm-Activation Model to Yard Burning. Journal of Applied Social Psychology, 8(2), 174-188. https://doi. org/10.1111/j.1559-1816.1978.tb00775.x
Van Riper, C. J., Lum, C., Kyle, G. T., Wallen, K. E., Absher, J., \& Landon, A. C. (2020). Values, Motivations, and Intentions to Engage in Proenvironmental Behavior. Environment and Behavior, 52(4), 437-462. https://doi.org/10.1177/0013916518807963

Wynveen, C. J., Wynveen, B. J., \& Sutton, S. G. (2015). Applying the Value-Belief-Norm Theory to Marine Contexts: Implications for Encouraging Pro-Environmental Behavior. Coastal Management, 43(1), 84-103. https://doi.org/10.1080/08920753.2014.989149 